\title{
Examination of the Perceptions on the View of Preschool Teachers About School Counselor ${ }^{*}$
}

\author{
Muhammet Ü. Öztabak \\ Correspondence: Assist. Prof. Muhammet Ü. Öztabak, Fatih Sultan Mehmet Vakıf University, Istanbul, Turkey.
}

Received: October 6, 2017

doi:10.11114/jets.v6i6.2682

\author{
Accepted: March 29, $2018 \quad$ Online Published: April 17, 2018 \\ URL: https://doi.org/10.11114/jets.v6i6.2682
}

\begin{abstract}
The responsibility of the development and the achievement of the child seems to be put on the shoulders of the preschool teacher. However, education is a teamwork in which not only teacher but also school administrator, family, school counselor (psychological counselor) and other supporting units should take active duty and work in cooperation. The school counselor plays an important role in following and supporting the child's bio-psycho-social development in this process. For all that, it is noteworthy that there is no effective cooperation between preschool teacher and school counselor. This study aims to investigate the perceptions of preschool teachers about school counselors. The data on school counselors' perceptions was collected by metaphor analysis method. Content analysis was used to classify the data. The study group of the research consisted of 221 preschool teachers working in European side of Istanbul during the academic year of 2016-2017. As a means of collecting data, teachers were asked to complete the sentence "School counselor is like ............. because ...........". Also the "personal information form" was used to obtain demographic information. Conceptual categories were created by analyzing the reasons why teachers prefered and used their spesific expressions to complete the survey. It was determined that the school counselor perceived positive expressions such as advisor, helper, guiding, problem solver, supporting.
\end{abstract}

Keywords: preschool teacher, school councelor, guidance, metaphor, perception

\section{Introduction}

The word metaphor originates from the Greek word metapherein ("to transfer"), where meta means "among" and pherein means "to bear, to carry". Therefore, in English language the word "metaphor" can signify "a transfer of meaning from one thing to another" (Gibbs, 1994: 210; as cited in Nikitina and Furuoka, 2008: 163). Metaphors have been identified by using Lakoff and Johnson's (1980:3) inclusive definition that is 'the understanding of one thing in terms of another'. A metaphor as a term is used as transferring the equivalent of something or just transferring. In most dictionaries, metaphor is described as comparing two things (Dur, 2006).

Metaphors are figures of speech in which one image or concept takes the place of (using to describe) another image or concept. They are so much a part of everyday communication that we hardly recognise them as figurative or metaphorical concepts (Pryor and Bright, 2009: 40). Metaphors help us to notice the inside of something and they also lead us to misinterpret the things. Metaphors have both strong and weak points. They do not only lead us to realize something but also lead us not to realize. As a result, there cannot be one metaphor suitable for every situation. Different metaphors have a power to uncover different dimensions of a situation and to show how different qualities can exist together (Morgan, 1998).

Metaphors can be seen as accepted communication tools (Hogler, Gross, Hartman, \& Cunliffe, 2008; Steger, 2007). They connect the experience and imagination together. They lead our comments and perceptions on reality and help us to state our imagination and aims clearly (Cornelissen, Oswick, Christenses, \& Phillips, 2008; Lopez, 2007). Metaphors may express and describe the concepts not only in a clear way but also in a detailed way (Sten, 2002). The meaning of the metaphor in conceptual field is having a relation between the field of concepts, field of knowledge, and the words (Heywood, Elena, \& Mick, 2002). At the same time, metaphors contribute to reveal how concepts are perceived (Cerit, 2008; Rızvanoğlu, 2007). Metaphors may be concrete or abstract as well as positive or negative. As a tool of getting information and examination, they can help the complex subjects to be understood easily (Semerci, 2007).

\footnotetext{
*This article was previously presented as an oral presentation at the 12th European Conference on Social and Behavioral Sciences, Catana/Sicily, Italy, January 25-28, 2017.
} 
Guidance and counselling is a process of helping people to become fully aware of themselves and the ways they respond to the influences of their environment. It further assists him or her to establish some personal meaning for this behaviour and to develop and classify a set of goals and values for future behaviour (Akinade, 2002). Guidance and psychological counseling services include psychological aids that are given to individuals by experts to solve their own problems, to make realistic decisions, to develop their capacities at the most appropriate level, to make a balanced and healthy adaptation to their surroundings and to ensure their self-actualization (Kuzgun, 1997; Kepçeoğlu, 1997). The aim of the guidance is to help people to be able to solve their problems, to reflect the solution in their behaviors, and to be a person who can solve his/her problems, by providing as possible as rich and accurate information about themselves and their surroundings. Because of this function, guidance is an integral part of the education system (Türkoğlu, 1997).

Counseling and guidance service provides services concerning developmental needs of an individual in personal and social areas such as developing awareness about interpersonal relationships beginning from the early ages; working on communication skills, life skills (Staley \& Carey, 1997). The principal aim of counseling and guidance services is to help students to accomplish the developmental tasks of the developmental stages they are in in a successful way (Myrick, 2003). Otlu (2011) indicates that the school counselor is one of the most important helpers in providing the social-emotional needs of children and adolescents and in the process of coping with adverse situations they face.

School counselors are expected to apply cognitive, affective, behavioral, and systemic intervention strategies (Hackney \& Cormier, 2008) to enable individuals to be mentally healthy (Myrick, 2003). Therefore they are expected to improve themselves in all the personal, social, academic, and vocational domains (American School Counselor Association-ASCA, 2007). Undergraduate or graduate degrees in psychological counseling and guidance is one main paths that lead them to be competent in their professions (Ergene, 2011).

In 2006, Ministry of National Education put Primary and Secondary Education Institutes Class Guidance Program into effect. According to this program, school counselors are primarily responsible to develop and implement the curricula for guidance. However; they cooperate with other staff at school for implementation. This program requires school counselors to consult class guidance teachers, to provide sources, materials and evaluation tools required, to determine incompetences by evaluating programs with class guidance teachers and to take needed precautions with class guidance teacher and the school principle while implementing the curriculum. In other words, success of school guidance while fulfilling his/her duties depends on cooperation with school managers, teachers, parents and everyone related to the school (Korkut-Owen \& Owen, 2008).

The psychological counselor helps the students to relieve their emotional problems and help them to find solutions more rationally to their personal problems, to develop their relations with other people, to define themselves, to develop a real self-perception, and to choose a profession that suits his/her qualifications and knowledge. It aims to reach a level of skill in which students can solve their own problems by activating the students' latent powers (Özgüven, 2000).

The school counselor serving at educational institutions offers counselling aid for a student to know and accept his/her personality which is constantly developing, to make decisions and choices concerning the upper stages, to deal with the problems faced with, to make the best use of his/her potential and thus reach self-actualization (Yeşilyaprak, 2001). The school counselors generally fulfill their primal aid activities, namely individual and group counseling, guidance, consultation, coordination, case management, guidance curriculum, program planning, management and evaluation (American School Counselor Association-ASCA, 2007; Fitch \& Marshall, 2004; Kuhn, 2004; Morrissette, 2000).

As the needs and developmental features of preschool education, elementary education, secondary education and university students differ from each other, the counseling and guidance services offered vary accordingly. Preschool stage is a critical stage during which the development is fast, the personality structure begins to take shape, the child is affected by his surroundings and is open to any kind of learning (Uz-Baş, 2007). In Turkey the aim of preschool education is to enhance the physical, cognitive and emotional development of children, support the acquisition of good habits, prepare children for primary education, ensure equity between all children and support the proper and correct use of the Turkish language (Ministry of National Education, 2006). In Turkey, early childhood education includes children aging from 3 to 5.5 years (36-66 months). It is provided in public or private kindergartens, application classrooms or nursery classes under the supervision of Turkish Ministry of National Education for a whole or half-day program (Ministry of National Education, 2012). Teachers working in these institutions graduate from preschool teacher departments of universities. The four-year education process includes theoretical and practical courses related to child development, program and curriculum development and some teaching skills.

One of the difficulties observed is that in preschool education responsibility of the development and achievement of the child is left to the preschool teacher. However, education is a teamwork in which not only teacher but also school administrator, family, school counselor (psychological counselor) and other supporting units should take active duty and work in cooperation. The school counselor plays an important role in following and supporting the child's bio-psycho-social development in this process. Psychological counseling and guidance services are carried out under 
the leadership of school counselor. However, this does not mean that the psychological counseling and guidance service is a task that should only be carried out by the school counselor. There seems to be lack of cooperation between pre-school teacher and the school counselor. This study aims to investigate the perceptions of preschool teachers about school counselor by means of metaphoric analysis.

\section{Purpose}

The main purpose of this study is to investigate the perceptions of preschool teachers about school counselor through metaphor analysis. In accordance with this main purpose, the following questions are asked to get answers:

1. What are the metaphors preschool teachers have developed regarding school counselor concept?

2. Under which categories can these metaphors expressed by preschool teachers be gathered in terms of common properties?

3. What role does the metaphors expressed by preschool teachers have in the foreground of the guidance teacher?

\section{Method}

\subsection{Research Model}

Researches trying to identify some events, objects, entities, associations, groups and various fields are defined as descriptive studies. These studies aim at explaining the interaction between the situations by taking into consideration of existing events and the previous events and their relations. Therefore, the current situations, conditions and characteristics are tried to be shown just as they are (Kaptan, 1998). This research is a descriptive study to reveal and analyze the current status. In this study, in order to determine the metaphors, a semi-structured form was given to preschool teachers to learn their perceptions about school counselors. For this purpose, preschool teachers were asked to complete a sentence in the following: "School counselor is like..... because......" The basic qualitative research model was adopted to collect, analyze and interpret data and technically metaphor analysis was used. Metaphor analysis allows the formation of qualitative data based on systematic stages such as listing, coding, categorizing, labeling of metaphors and calculation of compliance percentages (Schmitt, 2005). In this qualitative research, content analysis was performed during metaphor analysis.

\subsection{Study Group}

The study group of this research consists of 221 preschool teachers, 214 of whom are women and 7 of whom are men, working in the European side of Istanbul during the 2016-2017 academic year. A convenience sampling method was used to select participants of the study in order to describe their experience and perspectives. The demographic characteristics of the participants are given in Table 1.

Table 1. Demographics of participants

\begin{tabular}{llll}
\hline & & $\mathbf{f}$ & $\mathbf{\%}$ \\
\hline Gender & Male & 7 & 3 \\
& Female & 214 & 97 \\
\hline Age & $20-30$ age & 151 & 69 \\
& $31-40$ age & 54 & 24 \\
& 41 and more & 16 & 7 \\
\hline Educational degree & Occupational high school & 18 & 8 \\
& Pre-graduate & 67 & 30 \\
& Graduate & 128 & 58 \\
& Post graduate & 8 & 4 \\
\hline Duration of service & $0-5$ years & 122 & 56 \\
& $6-10$ years & 63 & 28 \\
& $11-15$ years & 23 & 10 \\
Marital Status & $16-20$ years & 5 & 2 \\
Have a child? & 21 and more years & 8 & 4 \\
\hline Type of the hight school & Single & 116 & 52 \\
& Married & 105 & 48 \\
& No child & 148 & 67 \\
& Have a child & 73 & 33 \\
& 1 child & 34 & 47 \\
& 2 child & 34 & 47 \\
\hline What kind of institution dou yo work? & 3 and more child & 5 & 6 \\
\hline & Public & 154 & 70 \\
& Private & 49 & 22 \\
\hline & Public & 217 & 98 \\
& Private & 4 & 2 \\
\hline & Public & 107 & 48 \\
& Private & 114 & 52 \\
\hline & Yes & 156 & 71 \\
& No & 65 & 29 \\
\hline
\end{tabular}




\subsection{Data Collection}

The data of this study were collected from preschool teachers working in various schools in Istanbul. After taking permission from the school administrations, teachers were contacted and face-to-face information was provided about the research. A secure atmosphere was tried to be provided for teachers to feel comfortable while responding the questions. Teachers were asked to complete the sentence "School counselor is like because .." They were given approximately 10 minutes to produce metaphors and they were asked to write the first metaphor that came into their minds. When metaphors are used as a research tool, the notion of "like" is often used to evoke the link between the subject of metaphors and the source of metaphors more clearly. It is also desired that preschool teachers should find a logical basis for their own metaphors with the concept of "because" (Saban, 2008). Moreover, teachers were given demographic information form in order to obtain data about their gender, age, educational degree, duration of service, marital status etc.

\subsection{Data Analysis}

During the data analysis, two expert researchers were informed on the issue and they were trained on how to follow the procedures. Among qualitative data analysis techniques, metaphor analysis was utilized for the examination of the data collected in the study. Analysis and interpretation of the metaphors were performed in four steps: 1) Codification and elimination, 2) Category improvement, 3) Providing validity and reliability, 4) Analyzing data quantitatively.

In codification and elimination step, all the metaphorical images supplied by the participants were coded. Forms that did not provide a rationale and a clear articulation of metaphorical images were eliminated. During the categorization step, generative categories were tried to be defined out of 100 surface metaphors. In order to assure validity and reliability of the study inter-coder reliability and Miles and Huberman's (1994) inter coder reliability formula was used (reliability = agreements / agreements + disagreements). To ensure the reliability of the study, the forms were examined by the researcher and two expert researchers. Data obtained by the two researchers were compared with the participation of the third researcher and "coherence" and "consistency" of the data were analyzed. Cohesiveness of two researchers' themes was analyzed by taking into account the principle arguing that qualitative data increases reliability (Yıldırım \& Şimşek, 2013). As a result of reliability calculation, the item agreement percentage of the scale was determined as 0.93 and it was accepted as reliable. In the last step, all the study data were entered into the SPSS program to calculate the frequencies (f) and percentages (\%) of the metaphorical images in each conceptual category.

\section{Findings}

In this section, the metaphors developed by the teachers participating in the research about the "school counselor" case are presented in tables. The findings are analyzed and interpreted as sub-titles according to the purpose questions.

\section{What are the metaphors preschool teachers have developed regarding school counselor concept?}


Table 1. Metaphors for school counselor concept

\begin{tabular}{|c|c|c|c|c|c|}
\hline Rank & Metaphors & $\mathbf{f}$ & Rank & Metaphors & $\mathbf{f}$ \\
\hline 1 & Brother-Sister & 1 & 51 & Guide & 16 \\
\hline 2 & Emergency help service & 2 & 52 & Book - Library & 4 \\
\hline 3 & Tree & 1 & 53 & Bridge & 4 \\
\hline 4 & Family counsellor & 1 & 54 & Savior & 7 \\
\hline 5 & Bulb & 1 & 55 & Norther & 1 \\
\hline 6 & Key & 1 & 56 & Magnet & 1 \\
\hline 7 & Mather or Father & 4 & 57 & Navigation & 1 \\
\hline 8 & Friend & 5 & 58 & Balance of school & 1 \\
\hline 9 & Enlightening & 2 & 59 & Heart of school & 1 \\
\hline 10 & Mirror & 3 & 60 & Foundation of school & 5 \\
\hline 11 & Walking stick & 2 & 61 & School brain & 1 \\
\hline 12 & Backbone & 1 & 62 & Pillar of the school & 3 \\
\hline 13 & Bilgisayar / Computer & 1 & 63 & River bed & 1 \\
\hline 14 & Building scaffolding & 1 & 64 & Myopics glasses & 1 \\
\hline 15 & Indispensable blessing & 1 & 65 & Indispensable & 3 \\
\hline 16 & Check-up program & 1 & 66 & Oxygen & 1 \\
\hline 17 & Effortful teacher & 1 & 67 & Ocean & 1 \\
\hline 18 & Door & 1 & 68 & Teacher & 4 \\
\hline 19 & Plane-tree & 1 & 69 & Teacher doctor & 1 \\
\hline 20 & Very important & 1 & 70 & Pedagogue & 4 \\
\hline 21 & Solution finder & 2 & 71 & Problem solver & 10 \\
\hline 22 & Consultant & 9 & 72 & Psychological counselor & 4 \\
\hline 23 & Lighthouse & 4 & 73 & Psychologist & 2 \\
\hline 24 & Supporter / Support force & 13 & 74 & Compass & 9 \\
\hline 25 & Domino & 1 & 75 & Character analyst & 1 \\
\hline 26 & Doctor & 2 & 76 & Wind & 1 \\
\hline 27 & Layout & 1 & 77 & Right-hand man & 4 \\
\hline 28 & Bread-Water & 1 & 78 & Hidden room & 1 \\
\hline 29 & Flashlight & 1 & 79 & Second teacher of the class & 1 \\
\hline 30 & Housewife & 1 & 80 & Confident & 1 \\
\hline 31 & Lantern & 2 & 81 & Eraser & 1 \\
\hline 32 & Opinion consultant & 1 & 82 & Waterfall & 1 \\
\hline 33 & Wardrobe & 1 & 83 & Signboard & 1 \\
\hline 34 & Shipwind & 1 & 84 & Team captain & 1 \\
\hline 35 & Secret support & 1 & 85 & Completed puzzle & 1 \\
\hline 36 & Candid camera & 1 & 86 & Therapy & 1 \\
\hline 37 & Rainbow & 1 & 87 & Scales & 1 \\
\hline 38 & Sun & 3 & 88 & Soil & 1 \\
\hline 39 & Educating the suns & 1 & 89 & Tour guide & 1 \\
\hline 40 & Harddisk & 1 & 90 & Consistent & 1 \\
\hline 41 & Wonderful & 1 & 91 & Pole completing the triangle & 1 \\
\hline 42 & Map & 1 & 92 & Veins of the body & 1 \\
\hline 43 & Light & 5 & 93 & Colorful flowers & 1 \\
\hline 44 & Medicine & 3 & 94 & Helpless & 5 \\
\hline 45 & Communication expert & 3 & 95 & Life well & 1 \\
\hline 46 & Irrelevant & 1 & 96 & Talent management department & 1 \\
\hline 47 & First-aid kit & 2 & 97 & Absent & 1 \\
\hline 48 & Joker & 1 & 98 & Music & 1 \\
\hline 49 & Wing & 1 & 99 & Router & 3 \\
\hline 50 & Explorer & 1 & 100 & Rubik's cube & 1 \\
\hline
\end{tabular}

2. Under which categories can these metaphors expressed by preschool teachers be gathered in terms of common properties?

When the participants' statements are analyzed, in total four conceptual categories are created from the metaphors they have produced: Problem Solver and Helper, Guide, Supporter and Ineffective Counselor.

\section{Category 1: School counselor as a Problem Solver and Helper}

In this category, it is seen that the preschool teachers perceive the school counselor as a Problem Solver and Helper and that they produce various metaphors on this subject. The frequency (f) and percent (\%) values of the metaphors expressed by the teachers are presented in Table 2 . 
Table 2. School counselor as a Problem Solver and Helper

\begin{tabular}{|c|c|c|}
\hline Metaphors & f & $\%$ \\
\hline Problem solver & 10 & 5 \\
\hline Emergency help service & 2 & 1 \\
\hline Individual psychologist & 2 & 1 \\
\hline Helper in difficult situation & 5 & 2.5 \\
\hline Psychological counsellor & 4 & 2 \\
\hline Support force & 13 & 6 \\
\hline Consultant & 9 & 4 \\
\hline Medicine & 3 & 1.5 \\
\hline Teacher & 4 & 2 \\
\hline Doctor teacher & 1 & 0.5 \\
\hline Pedagogue & 4 & 2 \\
\hline Right-hand man & 4 & 2 \\
\hline Veins of the body & 1 & 0.5 \\
\hline Pole completing the triangle & 1 & 0.5 \\
\hline Library-Book & 4 & 2 \\
\hline Indispensable blessing & 1 & 0.5 \\
\hline Check-up program & 1 & 0.5 \\
\hline Effortful teacher & 1 & 0.5 \\
\hline Plane-tree & 1 & 0.5 \\
\hline Solution finder & 2 & 1 \\
\hline Doctor & 2 & 1 \\
\hline Opinion consultant & 1 & 0.5 \\
\hline Candid camera & 1 & 0.5 \\
\hline First-aid kit & 2 & 1 \\
\hline Savior & 7 & 3 \\
\hline Ocean & 1 & 0.5 \\
\hline Eraser & 1 & 0.5 \\
\hline Therapy & 1 & 0.5 \\
\hline Pillar of the school & 3 & 1.5 \\
\hline Map & 1 & 0.5 \\
\hline Wing & 1 & 0.5 \\
\hline
\end{tabular}

When the Table 2 is examined, it is seen that the category of "problem solver and helper" is represented by 31 metaphors and 94 teachers (43\%). The most important of these categories are Support Force (13 teachers), Problem Solver (10 teachers), Consultant (9 teachers), Savior (7 teachers) and Helper in difficult situation (5 teachers).

Examples of direct expression of preschool teachers in this category are given below.

"Who are interested in the special situations of the students, their problems and who show the solutions." (Teacher 5)

"The person with whom I get help and support about the differences in the developmental processes and compliance issues of the students in my class." (Teacher 8)

"School counselor best knows the problem solving techniques and is the first unit to work with the prechool teacher in coordination." (Teacher 14)

"Person with broad framework for finding solutions." (Teacher 44)

"School counselor helps teachers and parents with the problems encountered, guides students when it is necessary and solves the problem in cooperation with prescool teachers as well." (Teacher 21)

\section{Category 2: School counselor as a Guide}

In this category, it is seen that the preschool teachers perceive the school counselor as a Guide and that they produce various metaphors on this subject. The frequency (f) and percent (\%) values of the metaphors expressed by the teachers are presented in Table 3.

When the Table 3 is examined, it is seen that the category of "guide" is represented by 26 metaphors and 64 teachers (29\%). The most important of these categories are Guide (17 teachers), Compass ( 9 teachers), Light (5 teachers) and Lighthouse (4 teachers).

Examples of direct expression of preschool teachers in this category are given below.

"The children or their families should consult on matters that are not sufficient, it is best to get help from experts in this regard." (Teacher 12)

"Directs the students to the appropriate destination." (Teacher 2)

"The teacher can be challenged when there are special children in the class (difficult children) and should be guided and 
supported about how to approach the child and what to do." (Teacher 26)

"Guides parents when they don't know how to direct their own children and also teachers and students when it is necessary. (Teacher 54)

Table 3. School counselor as a Guide

\begin{tabular}{lll}
\hline Metaphors & f & \% \\
\hline Guide & 16 & 7 \\
Router consultant & 3 & 1.5 \\
Compass & 9 & 4 \\
Lighthouse & 4 & 2 \\
Light & 5 & 2.5 \\
Sun & 3 & 1.5 \\
Wind & 1 & 0.5 \\
Life well & 1 & 0.5 \\
Norther & 1 & 0.5 \\
Signboard & 1 & 0.5 \\
Balance of school & 1 & 0.5 \\
Family counselor & 1 & 0.5 \\
Bulb & 1 & 0.5 \\
Enlightening & 2 & 1 \\
Mirror & 3 & 1.5 \\
Door & 1 & 0.5 \\
Flashlight & 1 & 0.5 \\
Lantern & 2 & 1 \\
Shipwind & 1 & 0.5 \\
Educating the suns & 1 & 0.5 \\
Navigation & 1 & 0.5 \\
Comleted puzzle & 1 & 0.5 \\
Explorer & 1 & 0.5 \\
River bed & 1 & 0.5 \\
Myopics glasses & 1 & 0.5 \\
Character analyst & 1 & 0.5 \\
\hline Counselor as a Supprter
\end{tabular}

\section{Category 3: School counselor as a Supporter}

In this category, it is seen that the preschool teachers perceive the school counselors as a Supporter and that they produce various metaphors on this subject. The frequency (f) and percent (\%) values of the metaphors expressed by the teachers are presented in Table 4.

When the Table 4 is examined, it is seen that the category of "supporter" is represented by 36 metaphors and 56 teachers $(25 \%)$. The most important of these categories are Foundation of school (5 teachers), Friend (5 teachers), Bridge (4 teachers) and Mather and Father (4 teachers).

Examples of direct expression of preschool teachers in this category are given below.

"Special cases that you can share." (Teacher 34)

"Guidance is like first aid, no matter which area and service you are in, you may need guidance from the individual." (Teacher 29)

"It can be helpful and supportive in difficult children and difficult parents." (Teacher 25)

"Every child needs an advisor, the school counselor should be preventative to avoid the problem." (Teacher 9)

"We have to face a lot of different events and people in our profession, but even if you know some things you need someone to show you different perspectives, a unit that will understand and support you when you get stuck is very important." (Teacher 32) 
Table 4. School counselor as a Supporter

\begin{tabular}{|c|c|c|}
\hline Metaphors & f & $\%$ \\
\hline Mather or Father & 4 & 2 \\
\hline Brother-Sister & 2 & 1 \\
\hline Communication expert & 3 & 1.5 \\
\hline Domino & 1 & 0.5 \\
\hline Bridge & 4 & 2 \\
\hline Second teacher of the class & 1 & 0.5 \\
\hline Scales & 1 & 0.5 \\
\hline Soil & 1 & 0.5 \\
\hline Backbone & 1 & 0.5 \\
\hline Very important & 1 & 0.5 \\
\hline Foundation of school & 5 & 2.5 \\
\hline Heart of school & 1 & 0.5 \\
\hline Indispensable & 3 & 1.5 \\
\hline Friend & 5 & 2.5 \\
\hline School brain & 1 & 0.5 \\
\hline Tree & 1 & 0.5 \\
\hline Key & 1 & 0.5 \\
\hline Walking stick & 2 & 1 \\
\hline Computer & 1 & 0.5 \\
\hline Building scaffolding & 1 & 0.5 \\
\hline Layout & 1 & 0.5 \\
\hline Bread-Water & 1 & 0.5 \\
\hline Wardrobe & 1 & 0.5 \\
\hline Secret support & 1 & 0.5 \\
\hline Rainbow & 1 & 0.5 \\
\hline Harddisk & 1 & 0.5 \\
\hline Wonderful & 1 & 0.5 \\
\hline Joker & 1 & 0.5 \\
\hline Magnet & 1 & 0.5 \\
\hline Oxygen & 1 & 0.5 \\
\hline Confident & 1 & 0.5 \\
\hline Waterfall & 1 & 0.5 \\
\hline Team captain & 1 & 0.5 \\
\hline Colorful flowers & 1 & 0.5 \\
\hline Rubik's cube & 1 & 0.5 \\
\hline Music & 1 & 0.5 \\
\hline
\end{tabular}

\section{Category 4: School counselor as Ineffective}

In this category, it is seen that the preschool teachers perceive the school counselors as Ineffective and that they produce various metaphors on this subject. The frequency (f) and percent (\%) values of the metaphors expressed by the teachers are presented in Table 5.

Table 5. School counselor as Ineffective

\begin{tabular}{lll}
\hline Metaphors & f & \% \\
\hline Consistent & 1 & 0.5 \\
Absent & 1 & 0.5 \\
Tour guide & 1 & 0.5 \\
Irrevelant & 1 & 0.5 \\
Housewife & 1 & 0.5 \\
Hidden room & 1 & 0.5 \\
Talent management department & 1 & 0.5
\end{tabular}

When the Table 5 is examined, it is seen that the category of "ineffective" is represented by 7 metaphors and 7 teachers (3\%). Examples of direct expression of preschool teachers in this category are given below.

"Must be friendly and positive, should not be hasty in the tests you have done." (Teacher 47)

"I work in the kindergarten section of a middle school with a high number of students, we have only one school counselor and even though we need her in the kindergarten, she cannot deal with pre-school students." (Teacher 33)

"Never come to class to recognize students, do not observe, do not care about students to direct to RAM (Guidance Research Center)" (Teacher 63)

"She is very unrelated to us and children, there is no solution when we have problems" (Teacher 62)

"As far as I can observe, the school counselor is sitting in the teachers" room until the end time of the day" (Teacher 80) 
"Her room was always there, but the door was always locked, was she there or was not, we never knew" (Teacher 207)

\section{What role does the metaphors expressed by preschool teachers have in the foreground of the guidance teacher?}

Table 6 shows the distribution of metaphors categorized by teachers participating in the survey on the concept of "school counselor".

Table 6. Distribution of metaphors by category

\begin{tabular}{|c|c|c|c|}
\hline Category & $\begin{array}{ll}\begin{array}{l}\text { Number } \\
\text { Metaphors }\end{array} & \text { of } \\
\end{array}$ & $\begin{array}{l}\begin{array}{l}\text { Number } \\
\text { Teachers }\end{array} \\
\end{array}$ & $\%$ \\
\hline Solver and Helper & 31 & 94 & 43 \\
\hline Guide & 26 & 64 & 29 \\
\hline Supporter & 36 & 56 & 25 \\
\hline Ineffective & 7 & 7 & 3 \\
\hline Total & 100 & 221 & 100 \\
\hline
\end{tabular}

When the Table 6 is examined, it is seen that $43 \%$ of the pre-school teachers participating in the research perceive the school counselor as "problem solver and helper", $29 \%$ as "guide", $25 \%$ as "supporter" and $3 \%$ as "ineffective". According to these data, preschool teachers perceive the school counselor as a person who solves the problems of the students and helps them.

\section{Conclusion, Discussion and Suggestions}

Education is generally seen as a special process between the student and the teacher, but in reality it is a teamwork. In this team, beside the class teacher, teachers of different branches, school administrators, school counselor (psychological counselor), family and other supporting units should have active duty and work in cooperation.

Preschool education is a special field of knowledge and skills. According to the impressions we have gained from previous field visits, it is observed that in preschool education responsibility for the development and achievement of the child is left to the preschool teacher and school administration. The school counseling has an important role in following and supporting the child's bio-psycho-social development in this process. For all that, it is noteworthy that there is no effective cooperation between preschool teacher and school counselor. In this study, the perceptions of preschool teachers of school counselor were examined by means of metaphor analysis. This study aimed to show the ways in which synergy could be created between the preschool teacher and the school counselor. Metaphors used by the preschool teachers show the degree of importance given to the profession of school counselor in preschools. However constraints experienced at the schools seems to rely all the responsibility on the shoulders of the preschool teachers.

When we look at the results of this research four categories; problem solver and helper, supporter, guide and ineffective metaphors were produced by preschool teachers. According to this, the school counselors were most perceived as Problem solver and helper, followed by Guide, Supporter and Ineffective respectively.

The first category that comes to foreground in this research is a preschool teachers' perception of school counselors as Problem Solver and Helper. The acquisition of problem solving skills by individuals is one of the main objectives of guidance. Looking at the mentality of guidance, it seems that there is also an approach that focuses on the incomplete aspects and malpractice of the individual and follows a path towards their solution (Şahin, 2010). Ginter, Scalise, and Presse (1990) have noted that teachers primarily look forward to the role of school counselors as helpers, facilitators and advisers. Wilgus and Shelley (1988) reported that school counselors gave priority to individual and group counseling in the study that examines the role of school counselors according to the perception of teachers.

The main function of psychological counseling and guidance services is to help students to complete the developmental tasks required for their developmental stage (Myrick, 2003). School counselors at school seem to be mainly concerned with problem children. Guidance is a process of helping an individual, but this includes not only problematic individuals but all individuals. This is especially important for infants, toddlers and preschoolers at preschools. In this period of time the child gives the hints of his or her developmental process. In case where there may be a problem, this could be diagnosed in the earlier developmental phases. At this point, the role of the preschool teacher is crucially important in ways of observing the child and understanding the child in terms of developmental competencies. It would be unfair to expect the preschool teacher to perform his or her responsibilities as a school counselor. Findings of this study reveals the importance of school counselors in preschools in ways of supporting children, families and teachers.

The second category found in this research is a preschool teachers' perception of school counselors as a Guide. Here, the school counselor is expected to guide not only the students but also the teachers and the parents. In other words, it is expected to be a leader. School counselors have an important leadership role in the development and implementation of school-based prevention programs in providing and maintaining a safe school atmosphere. This leadership role is perceived as coordinating and guiding all the stakeholders of the school. 
The third category obtained in the research is a preschool teachers' perception of school counselors as a "Supporter". Looking at the metaphors produced by the preschool teachers, it seems that the school counselor is the essential unit of the school. At the same time, they are perceived as reliable and confidential school personnel. The school counselor is perceived as the first person to contact and the closest person in any question.

The fourth category obtained in the research is a preschool teachers perception of school counselors as "Ineffective". All the teachers who participated in the research except seven teachers (3\%) expressed their positive opinions about the school counselor. These seven teachers used negative metaphors and explanations about school counselors. When analysed the rationale behind these teachers' negative attitudes, it was observed that many of them did not have the opportunity to work with a school counselor before due to the small number of teachers and the personelle allocated for their schools. In cases where there be school counselors, some of them were perceived as in effective due to the high number of students given for one school counselor at a big school. This finding seems to align with the experiences of the author in various academic site visits. In these informal visits, schools counselors were also given additional administrative responsibilities with the belief that they may have more available time when compared to preschool teachers. It could be interpreted from these results that the presence of a large number of students in some schools and the lack of staff influence the quality of guidance services. Classroom teachers are the key to conduct guidance services, but sufficient specialist staff should be assigned to primary schools by taking into account the student numbers. Furher studies could investigate the experiences of school counselors working in these large schools in comparison with the small preschools. This study revealed the metaphors used by preschools working in public schools. Experiences of the preschool teachers and the schools counselors could be examined in follow up studies in a way to provide a "counselling and guidance model for preschools".

Since the formation of psychological counselors in Turkey is more likely to work in secondary education, guidance services are not widely available in preschool education (Doğan, 2001; Yüksel-Şahin, 2008). It is suggested that the school counselor who will serve preschool classes should be supported with in-service training and workshop studies about the characteristics of preschool period. As a result, preschool teachers need help only in problems they can't solve. It can be said that the reason for this is due to the inadequate psychological knowledge and skills. They want the school counselor guide and help the students, parents and teachers. Almost all teachers stated that they accepted the school counselor as one of the basic element of education. School counselors are lack of education to deal with the 0-6 age group children. Play therapy, behavioral therapy techniques, projectives tests and techniques are used to solve the problems of these age group children. They aren't adequately taught in the university, they are given just introduction level education. School counselors are inadequate in solving the problems of the 0-6 age group students. That is why the cooperation beetween these two expert groups diminishes.

In cooperation with preschool teachers, a common understanding of guidance can be developed. More functional guidance services can be devoloped. More functional guidance program can be prepared by learning the expectations of the preschool teachers. More comprehensive guidance application can be created by taking into consideration the expectations of the teachers, administrators and parents into. Finally, the school counselor perception can be explored more comprehensively by taking the opinions of the other individuals related to guidance services.

In university, school counselors may be taught lessons about 0-6 age case analysis, preschool observation and child drawing. There is no spesific lesson in the curriculum of Higher Education Institution. Preschool Teacher Education curriculum includes courses named Classroom Management, Guidance and Child Mental Health. In these courses, students can be taught the methods of solving the behavioural problems of children.

Preschool teachers, school counselors and school administrators are expected to work in harmony in ways of implementing their "action research projects" in their school settings from an interdisciplinary perspective. In this respect, graduate education programs should also be tailored in line with the needs of teachers, students and families. Best practices implemented in the successful schools could be disseminated in ways of creating "communities of practice" (Hacifazlığlu et al, 2017). Therefore both preschool teachers and the school counselors are expected to be supported both in pre service and in service periods. They need to be constantly trained in recent trends and developments in early childhood education as well as creating better channels of communication with children and families.

\section{References}

Akinade, E. A. (2002). Concise counselling practicum. A basic text for colleges and universities. Ibadan, Olu Akin Publishers.

American School Counselor Association-ASCA (2007). Careers/Roles. Retrieved January 16, 2008, from http://www.schoolcounselor.org. 
Cerit, Y. (2008). Students, Teachers and Administrators' Views on Metaphors with Respect to the Concept of Principal. Education and Science, 33(147), 3-13.

Cornelissen, J. P., Oswick, C., Christensen, L. T., \& Phillips, N. (2008). Metaphor in organizational research: Context, modalities and implications for research introduction. Organization Studies, 29(7), 8-22. https://doi.org/10.1177/0170840607086634

Doğan, S. (2001). How can psychological and guidance services be configured in schools? VI. National Counseling and Guidance Congress. Ankara: ODTÜ Faculty of Education.

Dur, F. (2006). Understanding metaphor: A cognitive approach focusing on identification and interpretation of metaphors in poetry. Unpublished master thesis, Çukurova University, Institute of Social Sciences, Adana.

Ergene, T. (2011). Our effort to be named among health professions. Turkish Pscyhological Counseling and Guidance Association. Retrieved January 04, 2017, from https://www.pdr.org.tr.

Fitch, T., \& Marshall, J. L. (2004). What counselor do in high-achieving schools: a study on the role of the school counselor. Professional School Counseling, 7(3), 172-177.

Ginter, E. J., Scalise, J. J., \& Presse, N. (1990). The elementary school counselor's role: Perceptions of teachers. The School Counselor, 38, 19-23.

Hacıfazlığlu, O., Olson, K., Carlson, D., \& Clark, C. M. (2017). Theory becomes practice in community: Applying community of practice theory to doctoral education. In J. Mena, A. García-Valcárcel, F. J. G. Peñalvo \& M. M. Del Pozo (Eds.), Search and Research: Teacher Education for Contemporary Contexts (pp. 847-855). Algarve: University of Algarve Pub.

Hackney, H., \& Cormier, S. (2008). Psikolojik Danışma Illke ve Teknikleri: Psikolojik Yardım Süreci El Kitabı (Professional Counselor: A Process Guide to Helping). (Trans: T. Ergene \& S. S. Aydemir), Ankara: Mentis Publishing.

Heywood, J., Elena, S., \& Mick, S. (2002). Linguistic metaphor identification in two extracts from novels. Language and Literature, 11(35), 34-54. https://doi.org/10.1177/096394700201100104

Hogler, R., Gross M. A., Hartman, J. L., \& Cunliffe, A. L. (2008). Meaning in organizational communication: Why metaphor is the cake, not the icing. Management Communication Quarterly, 21, 393-412. https://doi.org/10.1177/0893318907309929

Kaptan, S. (1998). Bilimsel araştırma ve istatistik teknikleri (Scientific research and statistics technics). Ankara: Tekışık Printery.

Kepçeoğlu, M. (1997). Psychological counseling and guidance. (11. Edition). Başak Offset.

Korkut-Owen, F., \& Owen, D. (2008). The roles and functions of school psychological counselors: Opinions of managers and psychological counselors. Ankara University Educational Sciences Faculty, 41 (1), 207-221.

Kuhn, L. (2004). Student Perceptions of School Counselor Roles and Functions. Unpublised master's thesis. University of Maryland, Baltimore.

Kuzgun, Y. (1997). Psychological counseling and guidance. (5 Edition). Ankara: ÖSYM Publishing.

Lakoff, G., \& Johnson, M. (1980). Metaphors We Live By. Chicago: The University of Chicago Press.

Lopez, J. J. (2007). Notes on metaphors, notes as metaphors: The genome as musical spectacle. Science Communication, 29(7), 1-29. https://doi.org/10.1177/1075547007305165

Miles, M. B., \& Huberman, A. M. (1994). Qualitative data analysis. Thousand Oaks, CA: Sage.

Ministry of National Education (MEB) (2006). Okul öncesi eğitim programı: 36-72 aylık çocuklar için (Pre-school education program: for children aged 36-72 months). Ankara.

Ministry of National Education (MEB) (2012). 12 years compulsory education: Questions-answers. Ankara. Retrieved from http://www.meb.gov.tr/duyurular/duyurular2012/12yil_soru_cevaplar.pdf on December 9, 2016

Morgan, G. (1998). Metaphor in management and organization theories. İstanbul: Mess Publishing.

Morrissette, P. (2000). School counselor well-being. Guidance and Counseling, 16(1), 2-9.

Myrick, R. D. (2003). Developmental guidance and counseling: a practical approach. Minneapolis: Educational Media Corporation. 
Nikitina, L., \& Furuoka, F. (2008). Measuring Metaphors: A Factor Analysis of Students' Conceptions of Language Teachers. Metaphoric.de, 15, 161-180.

Otlu, B. M. (2011). Examination of coping strategies used by school psychological counselors in crisis intervention: Izmir provincial case. Doctoral Thesis, Dokuz Eylül University Institute of Educational Sciences, Educational Sciences Department, Guidance and Psychological Counseling Program, İzmir.

Özgüven, İ. E. (2000). Psychological counseling and guidance in contemporary education. (2. Ed.). Ankara: PDREM Publishing.

Pryor, R. G. L., \& Bright, J. E. H. (2009). Game as a career metaphor: a chaos theory career counselling application. British Journal of Guidance \& Counselling, 37(1), 39-50. https://doi.org/10.1080/03069880802534070

Rızvanoğlu, K. (2007). Intercultural understanding of metaphors in graphical user interfaces: a comparative study through a e-learning site in France and Turkey. Unpublished doctorate thesis, Marmara University Social Sciences Institute, Istanbul.

Saban, A. (2008). Metaphors about school. Educational Administration: Theory and Practice, 55, 459-496.

Şahin, C. (2010). Personality services and guidance in the education process. Psychological counseling and guidance, (3. Edition) (pp. 1-48). Ankara: Anı Publishing.

Schmitt, R. (2005). Systematic metaphor analysis as a method of qualitative research. The Qualitative Report, 10(2), 358-394.

Semerci, Ç. (2007). A View to the New Primary School Curricula With the Metaphors Relating to "Curriculum Development". Cumhuriyet University Journal of Social Sciences, 31(2), 125-140.

Staley, W. L., \& Carey, A. L. (1997). The role of school counselor in facilitating a quality twenty-first century workforce. School Counselor, 44(5), 377-383.

Steger, T. (2007). The stories metaphors tell: Metaphors as a tool to decipher tacit aspects in narratives. Field Methods, 19(3), 1-22. https://doi.org/10.1177/1525822X06292788

Sten, G. (2002). Towards a procedure for metaphor identification. Language and Literature, 11(17), 16-33. https://doi.org/10.1177/096394700201100103

Türkoğlu, A. (1997). Effective study methods to increase success. Journal of Education for Life, 55, 2-7.

Uz-Baş, A. (2007). Types of services in guidance. (Ed. B. Aydın), Rehberlik (Guidance) (pp. 82-116), Ankara: Pegem Publishing.

Wilgus, E., \& Shelley, V. (1988). The role of the elementary school counselor: Teacher perceptions, expectations, and actual functions. The School Counselor, 35, 259-266.

Yeşilyaprak, B. (2001). Guidance services in education. Ankara: Nobel Publishing.

Yıldırım, A., \& Şimşek, H. (2013). Qualitative research methods in the social sciences. (9. Edition). Ankara: Seçkin Publishing.

Yüksel-Şahin, F. (2008). Evaluation of school counseling and guidance services based on views of high school students. Journal of International Human Sciences, 5(2), 1-26.

\section{Copyrights}

Copyright for this article is retained by the author(s), with first publication rights granted to the journal.

This is an open-access article distributed under the terms and conditions of the Creative Commons Attribution license which permits unrestricted use, distribution, and reproduction in any medium, provided the original work is properly cited. 